ocated in Milwaukee, Wisconsin, Alשverno College is a small Catholic liberal arts college for women that features a unique ability-based curriculum and a rigorous tradition of assessment of student learning. The library plays an important role by providing resources and services that support the unique curriculum. Until recently, the collection development policy specified that library resources not include textbooks. However, in an effort to address concerns associated with rising textbook costs, student retention, and students' inability to purchase materials needed for their coursework, the library altered its policy and established an open reserve textbook collection.

There are plenty of reasons for academic libraries not to offer textbook collections, including prohibitive cost, rapid obsolescence, lack of space, lack of time, theft, competition from the campus bookstore, and a belief that students are responsible for buying their books. With so many reasons, academic librarians may feel justified holding on to practices that discourage collecting textbooks. Or they can chose a different path. Offering Open Educational Resources (OER) and other textbook alternatives would be ideal, however, advocating for campus-wide acceptance and implementation of OER can be a lengthy and time-consuming process. For this reason, Alverno librarians chose to offer a physical textbook collection in order to provide students with immediate relief from the financial burdens associated with high textbook costs.

This article discusses the rationale for incorporating textbooks into an academic library collection and the process of creating, organizing, and maintaining an open reserve textbook collection at the Alverno College Library.

\section{Addressing a need}

The rising cost of college textbooks is an increasingly important issue for college students and the librarians who serve them. Recent Consumer Price Index data show that consumer prices for college textbooks increased $88 \%$ over the time period from January 2006 to July 2016. This increase outpaced the 63\% increase for college tuition and fees and the 21\% increase for the much broader category of "all items."1

Skyrocketing textbook prices, when compounded with the burden of mounting student debt, results in an increasing number of students who are not getting their required textbooks. This is problematic because faculty cannot teach successfully when students do not have access to required reading or other learning material. In addition, when some students have

Dolores Skowronek is reference librarian/course reserves librarian at Alverno College, email: dolores.skowronek@ alverno.edu

() 2017 Dolores Skowronek 
the required materials and others do not, an inequality exists in the classroom that has direct impact on a student's ability to succeed, ${ }^{2}$ especially for first-year, firstgeneration students. ${ }^{3}$ This has potential impact for colleges and universities that strive to increase student retention rates. Institutions of higher education want students to be successful, and they want them to stay and graduate.

How many students are actually going without their textbooks? A recent survey of Florida university, college, and community college students found that $64 \%$ of respondents $(n=18,587)$ had not purchased a required textbook due to cost. ${ }^{4}$ In fall 2016 the Alverno College Library conducted a user survey of its own $(n=198)$ that resulted in a similar finding.

Overall, 51\% of Alverno students responded that they had not purchased a textbook due to cost. However, when the results were broken down by academic level, there was a cumulative effect for undergraduate students. By the time an Alverno student attained senior standing, $62 \%$ responded that they had gone without a textbook due to cost. The fact that students are not purchasing their textbooks is troubling and not without consequence. As reported by the Florida survey, consequences include taking fewer courses, not registering for a specific course, dropping or withdrawing from a course, and earning a poor grade or failing a course because the required textbook was too expensive. ${ }^{5}$

\section{An open reserve collection}

In an effort to fulfil its mission to support teaching and learning at Alverno College, a decision was made by library staff in March 2016 to pilot an open reserve textbook collection during the 2016-17 academic year with a goal of having the collection in place for the fall 2016 semester. The course reserves librarian was charged with developing and managing the pilot textbook project.
The decision to develop an "open" rather than a traditional "closed" reserve collection was made to remove usability barriers and provide students with easy access to the collection. As Stephanie PittsNoggle and Ryan Rafferty found in their 2015 survey of students at the University of Illinois-Chicago's satellite Library of the Health Sciences in Urbana, differences in usage and rates of user satisfaction indicate that open reserve collections better suit patrons' needs and is the more successful model for a reserve textbook collection. ${ }^{6}$

The Alverno Open Reserve Textbook Collection (AORTC) was modeled after the Library of the Health Sciences-Urbana's (LHSU) open reserve textbook collection but adapted to meet the needs of the Alverno student body. When LHSU students were specifically surveyed about the open reserves collection, the most agreed with statement (81\%) was that students liked being able to use materials without checking them out. This was followed closely by an equal number of students (77\%) who agreed that the collection was convenient, and that using the open reserves collection had saved them money. ${ }^{7}$ As expected, saving money was an important factor, but the most telling response was accessibility. With this in mind, Alverno librarians created a highly visible and browseable open textbook collection that fulfilled a genuine need on campus.

\section{Implementing a plan}

Planning, organizing, and maintaining the AORTC pilot project proved to be a formidable task, but was achieved through buy-in from library staff, cooperation and support from other departments on campus, and an adherence to a strict timeline. Having one person responsible for coordinating all the players involved also proved extremely valuable and ensured that textbooks were available to students at the beginning of the fall 2016 semester. The initial steps of planning AORTC focused on feasibility. This included meet- 
ing with Alverno's bookstore manager to confirm that the college's contract with its textbook vendor did not prohibit the library from placing textbooks on reserve. Next steps included obtaining a complete list of courses and textbooks for the upcoming semester from the vendor, exploring options for integrating records into the OPAC, and securing bookshelves and space to house the new collection. Once these initial steps were attended to, developing selection criteria, financing AORTC, purchasing and processing books, determining checkout periods and fines, and providing accessibility were the next challenges.

\section{Selection criteria}

Before selection criteria could be established, the list of courses and textbooks provided by the college's textbook vendor was closely examined to identify required textbooks. The list was also used to determine if current editions of textbooks were already in the library's collection. These were identified and pulled for AORTC, including instructors' personal copies found in the closed reserve collection. Tattle tape was added to all personal copies to prevent theft. This phase of the process was labor intensive and very time consuming. It was also dependent on the textbook vendor providing a list well in advance of the beginning of the semester. In addition to using the vendor list to identify potential titles to purchase, the interlibrary loan supervisor suggested several frequently requested books, which were purchased and added to AORTC.

Due to a limited budget, the library did not purchase every required textbook. The task of deciding which textbooks to purchase was left to the subject liaisons. The selection criteria considered most important were enrollment and cost. Liaisons were encouraged to purchase books for classes with high enrollment and, realizing that cost has implications for students' ability to succeed, liaisons were also encouraged to purchase expensive textbooks. Generally, the library purchased only one copy of a textbook. Exceptions were made for high demand titles, classes with high enrollment, and for titles that could be purchased at low cost, such as books required for a popular "Oprah's Books" English course.

AORTC consisted almost entirely of undergraduate textbooks, however a small number of graduate textbooks were added if requested by faculty. If an ebook was available for purchase through the library's ebook vendor Ebook Central, that version was purchased rather than print in order to make the book more accessible. Unfortunately, very few textbooks were available for purchase as Ebook Central ebooks, and they made up less than 5\% of AORTC.

\section{Financing the collection}

Financing AORTC required creativity and support from across campus. The library set aside an initial dollar amount of $\$ 5,000$ of its capital budget to purchase textbooks. In the early planning stages, subject liaisons also contacted instructors and requested textbook donations. Donations were also solicited from department heads on campus and the college's Center for Academic Excellence. These strategies were successful and resulted in generous donations for the new collection.

The library also encouraged students to donate gently used textbooks by holding a book drive in late 2016. This strategy proved unsuccessful. While the library did receive donations, few were acceptable for the textbook collection. Of the 42 books donated, only five were added to AORTC.

Despite efforts to supplement the new collection with donated materials, the initial $\$ 5,000$ was not enough to build a new textbook collection for the entire academic year. The initial budget was 
overspent by $\$ 1,362$, which came out of the library's book budget.

\section{Checkout periods and fines}

Open reserve collections provide flexibility because students can choose to use a textbook in-house or choose to check it out. For students who choose to check items out, longer checkout periods are preferred. ${ }^{8}$ However, longer checkout periods can limit access for other students, unless multiple copies exist in the collection. In order to add equity, a decision was made to tier the checkout periods depending on the number of copies of an individual title and the nature of the book. Nonfiction textbooks were assigned a four-hour checkout period unless there were multiple copies. For titles with multiple copies, the first copy was assigned a four-hour checkout period with all other
Others paid fines up to $\$ 50$ for each item that was returned late.

\section{Access and promotion}

One of the primary goals of an open reserve collection is to provide convenience and optimal accessibility. With this in mind, a highly visible spot in the library's main reading room was chosen for AORTC. An online reserve course was also created in the library's OPAC to make the textbooks "findable" online. All textbooks records were added to the reserve course and "tagged" with a public note indicating the course number. This allowed students and library staff to quickly find textbook records online.

Aside from notifying instructors about the textbook collection, AORTC was not widely promoted. Given that the collection did not include multiple copies

\section{Semester Number of Number of checkouts and Average use Number of zero items in-house use combined \\ Spring 2017 \\ 329 \\ 1,126 \\ per item \\ 3.4 \\ 101}

copies assigned a three-day checkout. For novels (such as Oprah's Book Club books), all copies were assigned a sevenday checkout period.

A valid concern associated with textbook collections is that students will not return books when due. For expensive textbooks, students can in fact save money by keeping a book for an entire semester and paying a fine when the book is returned late. In order to discourage students from taking advantage of the collection in this manner, overdue notices were sent to a student's campus email account, and steep fines were assigned and charged for overdue books. Fines were not forgiven, except for extenuating circumstances. A bookmark was placed in each textbook spelling out the overdue policy and included a notice that fines would not be waived. For the most part, students were respectful and returned books when due. of most textbooks, a lack of promotion was intentional. Librarians felt that heavily promoting the collection would give students the impression that they could rely entirely on the library for all their textbook needs. That was never the intention, as the collection was designed to supplement rather than entirely fulfill a student's textbook needs.

Despite little effort to promote the collection, word of mouth quickly spread across campus and students became aware of AORTC. Usage statistics show that the collection was heavily used.

\section{Usage statistics}

To gauge the overall success of the pilot textbook project, usage data were analyzed (see Figure 1). Unfortunately, despite efforts to collect reliable usage statistics, data reports for fall 2016 were not considered accurate or comprehen- 
sive. As a result, library staff gained a better understanding of how to monitor usage and generate reliable data reports for spring 2017. These reports provided insight into how AORTC was used. It should be noted that efforts were made to track in-house usage. However, it is unlikely that all in-house data were captured and these numbers represent a conservative estimate of actual use.

Based on data for spring 2017, AORTC usage was highest during the first three weeks of the semester, with approximately $36 \%$ of textbook circulation occurring during these early weeks. When usage data for titles with highest circulation were examined, reports show that the top ten most frequently circulating titles comprised $42 \%$ of total textbook circulation, and all but one of these titles was for a freshman- or sophomore-level course.

The average "new book" bookstore cost for the top ten titles was \$198.05. These numbers support acquiring higher cost textbooks for lower level undergraduates, and indicate that AORTC provided a valuable cost-saving service for Alverno students. Future iterations of the textbook collection will focus on optimizing cost effectiveness and reducing the number of zero-use items.

\section{Conclusions}

The decision to offer Alverno students an open reserve textbook collection was driven entirely by student need. While time consuming and labor intensive, the pilot project was a success and the collection will become part of the library's offerings. However, sustaining the collection will become increasingly difficult as its popularity continues to grow.

For this reason, future plans include working with administration and faculty to raise awareness of the implications of textbook costs and the need to explore textbook options such as OER. Unfortu- nately, high-quality OER are currently not available to fulfill every teaching need-making traditional textbooks the best option for many instructors. Librarians who acknowledge this and set aside arguments for excluding textbooks from their collections are better positioned to elevate the value of the library on campus.

Because the value of a library is related to how well it satisfies the needs of its users, providing an essential resource that addresses an immediate financial need goes a long way towards helping students succeed in their courses.

\section{Notes}

1. Bureau of Labor Statistics, U.S. Department of Labor, "College Tuition and Fees Increase 63 Percent since January 2006," TED: The Economics Daily. Last modified August 30, 2016, https://www.bls.gov/opub /ted/2016/college-tuition-and-fees -increase-63-percent-since-january-2006. htm.

2. James A. Buczynski, "Faculty Begin to Replace Textbooks with "Freely" Accessible Online Resources," Internet Reference Services Quarterly 11, no. 4 (2006): 169-79, doi:10.1300/J136v11n04_11.

3. Phil Hill, "Students Are Spending Less on Textbooks, But That's Not All Good," The Chronicle of Higher Education, February 25, 2016, www.chronicle.com/article/Students -Are-Spending-Less-on/235340.

4. Florida Virtual Campus, 2012 Florida Student Textbook Survey, Tallahassee, Florida, 2012, www.openaccesstextbooks.org /pdf/2012_Florida_Student_Textbook _Survey.pdf.

5. Ibid.

6. Stephanie Pitts-Noggle and Ryan Rafferty, "Investigating Textbook Reserves: A Case Study of Two Models for Reserves Collections," College \& Research Libraries 78, no. 1 (2017): 66-79, doi:10.5860/ crl.78.1.66.

7. Ibid.

8. Ibid. $\neq 2$ 